\title{
Література
}

1. Андрущенко В. П. Роздуми про освіту: статті, нариси, інтерв'ю / В. П. Андрущенко. - К. : Знання України, 2004. - 804 с.

2. Вовковінська Н. В. Як створити комп’ютерну презентацію / Н.В. Вовковінська. - К. : Шкільний світ, 2009. - 128 с.

3. Гершунский Б. С. Компьютеризиция в сфере образования: проблемы и перспективы / Б. С. Гершунский. - М., 1987. - 264 с.

4. Савченко О. Удосконалення професійної підготовки майбутніх вчителів початкових класів / Олександра Савченко // Початкова школа. - 2001. - №7. - С. 1-4.

5. Сиротенко К. Інформаційні технології - чинник формування Школи майбутнього / К.Сиротенко // Директор школи. - 2010. - №6. - С. 5-8.

6. Селевко Г.К. Современные образовательные технологии : [учебн. пособ.] / Г.К. Селевко. - М., 1998. - 256 с.

7. Слєпкань 3. I. Наукові засади педагогічного процесу у вищій школі: [навч. посіб.] / 3. І. Слєпкань. - К.: Вища школа, 2005. - 239 с.

Стаття надійшла до редакції 19.05.2012 р.

УДК [377.36.011.3-051

О. А. Одинець, acniрант, Луганський національний університет імені Тараса Шевченка

\section{ПРОФЕСІЙНА ПІДГОТОВКА КОМПЕТЕНТНОГО ФАХІВЦЯ З ПЕРУКАРСЬКОГО МИСТЕЦТВА ТА ДЕКОРАТИВНОЇ КОСМЕТИКИ ЗАСОБАМИ МИСТЕЦТВА}

Одинець О.А. Професійна підготовка компетентного фахівия з перукарського мистеитва та декоративної косметики засобами мистецтва.

У статті розглядається поняття «професійна підготовка» та ії структура, аналізуються різні підходи до визначення сутності поняття «компетентність», «засоби мистецтвва».

Ключові слова: професійна підготовка, компетентність, засоби мистецтва.

Одинец Е.А.Профессиональная подготовка компетентного специалиста по парикмахерскому искусству и декоративной косметике средствами искусства.

В статье рассматривается понятие «профессиональная подготовка» и ее структура, анализируются разные подходы к понятию «компетентность специалиста».

Ключевые слова: профессиональная подготовка, компетентность, средства искусства.

Odinets E. The training of a competent professional in hairdressing and make-art methods.

This article discusses the concept of «training» and its structure are analyzed different approaches to the concept of «competence of a specialist».

Key words: training, competence, complex art.

У Законі України «Про освіту» зазначено: «Метою освіти є всебічний розвиток людини як особистості та найвищої цінності суспільства, розвиток іiі талантів, розумових і фізичних здібностей, виховання високих моральних якостей, формування громадян, здатних до свідомого суспільного вибору, збагачення на цій основі інтелектуального, творчого, культурного потенціалу народу, забезпечення народного господарства кваліфікованими фахівцями» [4, с. 6].

Однією з актуальних проблем нині варто назвати модернізацію системи підготовки у ВНЗ I-II рівня акредитації, яка допоки не відповідає оновленим 
вимогам та не забезпечує достатній рівень формування готовності фахівців 3 перукарського мистецтва та декоративної косметики до професійної творчої діяльності. Важливою проблемою залишається пошук ефективних шляхів, забезпечення необхідних і достатніх умов для вдосконалення процесу формування особистості перукаря-модельєра як висококваліфікованого фахівця, здатного до самореалізації в професійній та творчій діяльності відповідно до соціального замовлення.

Незважаючи на певну увагу до проблеми професійної підготовки майбутніх фахівців 3 перукарського мистецтва та декоративної косметики, донині вона не була предметом актуальних дисертаційних та монографічних досліджень, але обгрунтуванню психології творчості, особливості творчої уяви та сприйняття приділялося достатньо уваги багатьма науковцями (А. Бодалев, А. Ухтомський, Б. Мейлах, И. Блауберг, Е. Юдін). Нині під час теоретичної та практичної підготовки фахівців 3 перукарського мистецтва та декоративної косметики використовуються навчальні підручники та посібники $[3 ; 5 ; 6 ; 11]$.

Вважаємо за доцільне сформувати мету статті, яка полягає у теоретичному обгрунтуванні сутності професійної підготовки майбутнього компетентного фахівця в галузі «Мистецтво» у ВНЗ І-ІІ рівня акредитації.

Педагогічна енциклопедія надає змогу встановити сутнісний зміст поняття «професійна підготовка» як «сукупність спеціальних знань, умінь $\mathrm{i}$ навичок, якостей, трудового досвіду і норм поведінки, що забезпечують можливість успішної роботи з певної професії» [10, с. 573]. Проте головною визначальною характеристикою фахівця - $є$ компетентність. Компетенції характеристики, необхідні фахівцю для виконання певних функцій. До професійних компетенцій відносять знання, уміння, навички та ставлення до професійних обов'язків [12, с. 123].

У нашому дослідженні ми дотримуємося думки, що проектування, створення та реалізація кваліфікованим фахівцем з перукарського мистецтва художнього образу має відповідати основним функціям у майбутній професійній діяльності фахівця в галузі «Мистецтво», зокрема таким: проектувальна; організаційна; управлінська; технологічна; контрольна; прогностична; технічна. Для виконання кожної з цих функцій фахівець 3 перукарського мистецтва та декоративної косметики має володіти відповідною системою вмінь (компетенцій) та знати:

- державні нормативно-правові акти, методичні й нормативні матеріали з питань професійної сфери діяльності;

- склад, компоненти декоративної косметики та перукарських засобів;

- особливості типу шкіри, структури волосся людини;

- техніку виконання стрижок, зачісок, хімічної завивки, фарбування, колорування, моделювання волосся;

- технологію нанесення декоративної косметики; види якісної декоративної косметики, фарб та лаків для волосся тощо;

- основи професійної етики та технічної естетики;

- передовий вітчизняний та світовий досвід з перукарського мистецтва; 
- вимоги з охорони праці, техніки безпеки та екології.

Уміти:

- аналізувати сучасні проблеми розвитку перукарського мистецтва;

- орієнтуватися в реаліях розвитку перукарського мистецтва та декоративної косметики, оцінювати його стан та перспективи;

- застосовувати досягнення відомих стилістів, перукарів, візажистів у розв'язанні виробничих завдань;

- використовувати знання 3 історії мистецтв, малюнка, живопису, кольорознавства, історії костюма і зачіски;

- мати високу культуру мислення, вміти чітко і логічно висловлювати свої думки як усно, так і письмово державною та іноземними мовами;

- досконало володіти комп'ютером, сучасними інформаційними технологіями та застосовувати їх у своїй професійній діяльності;

- бути готовим до самоосвіти, опанувати новими знаннями, критично оцінювати наявний світовий досвід та набувати власний; розуміти основні проблеми своєї професії, що визначають конкретну галузь його діяльності;

- володіти всіма видами мовленнєвої діяльності на основі достатнього обсягу знань з фонетики, граматики, лексики;

- уміти творчо підходити до технологічного процесу в різних ситуаціях;

- використовувати знання 3 основ емоційно-чуттєвого сприйняття форми, основи теорії та методології перукарського мистецтва та декоративної косметики, основ моделювання та колористики;

- виконувати правила системи управління якістю продукції та послуг охорони праці;

- уміти розробляти варіанти образів та їх демонстрації [2].

Зважаючи на вище зазначене, доцільно з'ясувати психолого-педагогічну сутність кваліфікованої підготовки фахівців та методів, за допомогою яких може здійснюватися ця підготовка. На це питання ми знаходимо відповідь у відомій праці засновника вітчизняної психологічної науки Л. Виготського «Психологія мистецтва» [1, с. 69-71], де, зокрема, розглядається співвідношення між формою та прийомом мистецтва та зазначається, що прийом - не самоціль, він набуває певного смислу лише у відповідній формі. 3 огляду на це можна зробити висновок, що засіб мистецтва вже стає категорією не стільки етичною (мистецькою), скільки педагогічною, як компонент педагогічного процесу. Відповідну форму ми розглядаємо як компонент педагогічної системи, яку назвали комплексом мистецтв.

Історичний досвід свідчить, «що природа мистецтва поліфункціональна i багатозначна, а тому розкрити його роль і місце в житті суспільства можна лише за умови врахування всіх його функцій у складному діалектичному взаємозв'язку. У процесі розвитку мистецтва відбувається модифікація його функцій, у яких виявляється специфіка мистецтва як форми духовного виробництва, форми суспільної свідомості, яка всебічно сприяє цілісному духовному розвитку особистісний» [13, с. 298].

У контексті педагогічного підходу щодо впливу мистецтва дуже 
важливо враховувати психологічний аспект. Справа в тому, що сутність мистецтва прихована в глибинних психологічних утвореннях людини й суспільства. На цій особливості акцентував увагу відомий вітчизняний психолог О. Леонтьєв у роботі «Деякі проблеми психології мистецтва» [9]. Ця проблема належить до категорії проміжних між естетикою і психологією. Специфічна функція мистецтва полягає у катарсисі, тобто очищенні, викоріненні афектів, пристрастей. Продуктом такої діяльності $\epsilon$ трансформовані, очищені, сублімовані емоції та почуття. О. Леонтьєв наголошував, що мистецтво становить ту єдину діяльність, яка відповідає завданням відкриття та вираження дійсності й реальності і $\epsilon$ шляхом морального та духовного зцілення й очищення.

Видатний швейцарський психолог К. Юнг у своїх роботах з психології мистецтва [14] вказував на існування двох принципових різновидів творчості «сентиментальної», або інтровертивної, та «наївної», або екстравертивної. У першому випадку людина сама творить мистецтво за рахунок власних здібностей та психологічних можливостей. У другому випадку вона $\epsilon$ своєрідним інструментом у процесі народження твору мистецтва, коли він 3 неї випливає. У такі моменти свідоме мислення відходить на задній план. Юнг також попереджав, що психологічні механізми народження такого твору схожі на виникнення неврозу. I тому людині, що сприймає художній твір, важливо поринати у нього лише настільки, наскільки це необхідно для неї самої, розуміння своїх почуттів та емоцій у контексті власної особистості та етичних цінностей. Це важливо враховувати і під час використання засобів мистецтва в навчально-виховному процесі.

У контексті нашої проблеми доцільно нагадати думку відомого психофізіолога I. Павлова про те, що життя чітко розподіляе людей на художників i мислителів [7], яка засвідчує фізіологічне підгрунтя висунутого нами припущення стосовно впливу мистецтва на особистість фахівця. Художники цілісно охоплюють дійсність без їі подрібнення і роз'єднання, оживляють їі, а мислителі навпаки, іiі подрібнюють, немов би умертвляють, щоб потім створити щось нове, проте це не завжди їм вдається. Отже, у навчальновиховному процесі завжди мають місце дві сили: розум та мислення, емоції та почуття. На нашу думку, саме педагогічний чинник характеризує розум та мислення, а мистецький - емоції та почуття. Завдяки використанню засобів мистецтва можемо розумно, а значить оптимально регулювати співвідношення цих сил. Слід зазначити, що теоретичні наукові знання, що завжди були складником навчального процесу, самі по собі не можуть бути критерієм компетенції перукаря-модельєра, цього можна досягти лише застосуванням мистецтва, як засобу оновлення навчально-виховного процесу шляхом розроблення педагогічних технологій та їх використанням.

Можна також погодитися 3 думкою науковців, що всі види мистецтва однаковою мірою беруть участь у створенні об’єктивної картини світу і тому повноцінно можуть використовуватися у підготовці фахівців з перукарського мистецтва та декоративної косметики. Немає головних видів мистецтва i 
другорядних, високих і низьких, хоча в історії розвитку мистецтва відомі періоди, коли який-небудь один вид мистецтва був домінантним 3-поміж всіх інших.

У системі мистецтв важливе місце посідають література, музичне, образотворче мистецтво, їх покладено в основу синтетичних мистецтв, саме від них розпочався поділ на види. Ми спробуємо через кожен окремий вид мистецтва, його специфіку розвитку відкрити багатство потенційних можливостей мистецтва у підготовці майбутніх перукарів-модельєрів до професійної творчої діяльності.

Ураховуючи психологічні особливості мистецтва [1;8], особливу увагу слід звернути не стільки на якомога вищий рівень розвитку мистецької майстерності фахівця з перукарського мистецтва та декоративної косметики, скільки на рівень необхідного й достатнього заглиблення в методи та засоби певної педагогічної технології в процесі підготовки фахівців галузі «Мистецтво». Важливо, щоб цей метод чи засіб не поглинали один одного. Засіб мистецтва має бути лише необхідним інструментом у педагогічному процесі.

Отже, аналіз психолого-педагогічної літератури і практичної діяльності дозволяє стверджувати, що нині проблема професійної підготовки перукарівмодельєрів $є$ досить актуальною, пріоритетним та багатоаспектним утворенням. Педагогічна підготовка у ВНЗ I-II рівня акредитації має бути спрямована на досягнення головної мети навчання - становлення органічної цілісної системи, яка утверджує людину як найвищу соціальну цінність та забезпечує грунтовний загальнокультурний, творчий, креативний розвиток особистості майбутнього фахівця з перукарського мистецтва та декоративної косметики.

Це дозволить надалі подолати об'єктивно функціональну суперечність між постійно змінними вимогами до фахівців і можливостями системи освіти, оскільки соціально-політичні та суспільно-політичні чинники не тільки впливають на загальні перспективи розвитку освіти, але й висувають принципово нові вимоги до всіх його структур.

Уважаємо, що в подальшому слід розробити сучасні педагогічні технології з використанням засобів мистецтва (музики, літератури, архітектури, скульптури, образотворчого мистецтва тощо), ураховуючи специфіку компетентностей фахівців галузі «Мистецтво» та раціональні методики їх застосування. Перспективним $є$ використання інформаційних систем для забезпечення нової якості освітніх технологій шляхом моделювання в навчально-виховному процесі принципів і засобів мистецтва та створення міждисциплінарних навчально-методичних комплексів з художньо-естетичної освіти і виховання.

\section{Література}

1. Выготский Л. С. Психология искусства / предисловие Леонтьева А. Н.; комент. Л. С. Выготского, В. В. Иванова; общ. ред. В. В. Иванова. - [3-е изд.]. - М. : Искусство, 1986. - C. 31-71.

2. Галузевий стандарт ВО України, ОКХ, 6.020207 «Дизайн», 5.02020702 «Перукарське мистецтво та декоративна косметика», 3471 «Фахівець 3 перукарського мистецтва та декоративної косметики» МОіН України, Київ, 2008.

3. Гутыря Л.Г. Парикмахерское искусство / Л. Г. Гутыря. - Х.: Фолио, 2005. - 464 с.

4. Закон України «Про освіту» // Освіта. - 21 серп. 1996 р. - № 43-44 (221-222). - С. 6-11. 
5. Коваленко И. В. Изготовление шиньонов и париков и прически из них / И. В. Коваленко. - Ростов-на-Дону: Феникс, 2004. - 224 с.

6. Константинов А. В. Парикмахерское дело : [практ. пособ.] / А. В. Константинов. М. : Высшая школа, 1987. - 336 с.

7. Кудін В. О. Естетичне в педагогічній методології професії // Неперервна професійна освіта: теорія і практика: [зб. наук. праць] / за ред. І. А. Зязюна та Н. Г. Ничкало. - Ч.1. - К., - 2001. - С. 27-30.

8. Леонтьев А. Н. Деятельность. Сознание. Личность / А. Н. Леонтьев. - М. : Политиздат. - 1975. - 138c.

9. Леонтьев А. Н. Избранные психологические произведения / А. Н. Леонтьев. -Т. 2. М. : Педагогика, 1983. - С. 232-240.

10. Педагогическая энциклопедия / гл. ред. Каиров А. И. - М. : Сов. энциклопедия, 1988. - Т.3. - 880 с.

11. Перукарське мистецтво: [підручник для учнів проф.-тех. навч. закладів] / В. Ф. Орлов (заг. ред.). - Кн.1: Історія перукарської справи. - К. : Грамота, 2005. - 351 с.

12. Хуторской А. В. Дидактическая эвристика. Теория и практика креативного обучения / А. В. Хуторской. - М. : МГУ, 2003. - 416 с.

13. Шевченко Г.П. Взаємодія мистецтв в естетичному вихованні підлітків / Г. П. Шевченко.- К. : Знання, 1981. - 298 с.

14. Юнг К.Г. Психоанализ и искусство / К. Юнг, Э. Нойман. - К. : REFL-book, ВАКЛЕР, 1996. - С. 9-29.

Стаття надійшла до редакції 14.05.2012 р.

Г. Б. Бреславська, викладач,

Миколаӥвський національний університет ім. В. О. Сухомлинського

\section{ПРОЕКТНА ДІЯЛЬНІСТЬ ЯК ЗАСІБ ФОРМУВАННЯ ПРОФЕСІЙНОЇ КОМПЕТЕНТНОСТІ МАЙБУТНЬОГО ВЧИТЕЛЯ}

Бреславська Г. Б. Проектна діяльність як засіб формування професійної компетентності майбутнього вчителя.

У статті розкрито питання проектної діяльності як одного із засобів формування професійної компетентності майбутнього вчителя, висвітлено можливості застосування методу проектів у фаховій підготовиі студентів.

Ключові слова: проект, проектна діяльність, професійна компетентність

Бреславская А.Б. Проектная деятельность как средство формирования профессиональной компетентности будущего учителя.

В статье раскрывается вопрос проектной деятельности как одного из средств формирования профессиональной компетентности будущего учителя, показаны возможсности применения метода проектов в профессиональной подготовке студентов.

Ключевые слова: проект, проектная деятельность, профессиональная компетентность.

Breslavskaya A. Project activity as a means of the formation of professional competence of future teachers.

The article deals with the problem of project activity as a means of the formation of professional competence of future teachers. The author shows the possibilities of the project method for students' professional training.

Key words: project, project activity, professional competence. 